\title{
Deprecjacja kobiet w uwarunkowanych stereotypowo wypowiedziach mężczyzn w polskich dyskursach politycznych w latach 2016-2017
}

\begin{abstract}
Streszczenie: Celem artykułu jest przeanalizowanie językowych sposobów jawnej deprecjacji kobiet przez polskich polityków i publicystów w kontekście wypowiedzi wymierzonych przeciwko zaostrzeniu przepisów o aborcji. Osoby sprzeciwiające się zmianom w tej ustawie zdecydowały się na organizację manifestacji ulicznych, nazwanych „,czarnymi protestami”. Zdecydowaną większość manifestantów stanowiły kobiety. Seksualność człowieka postrzegana jest między innymi przez pryzmat kultury, w której stereotyp odgrywa dominującą rolę. W polskim dyskursie publicznym kobieta jest obrazowana przede wszystkim w oparciu o dwa stereotypy: matki i feministki. Stały się one podstawą metodologicznej konstrukcji tego artykułu. Analizie zostały poddane wypowiedzi odnoszące się do wartościowania poglądów i postaw kobiet biorących udział w akcjach protestacyjnych. Z badanych tekstów wynika, iż w dyskursie politycznym coraz trudniej o zachowania oparte na normach obowiązującej dotychczas grzeczności językowej. Batalia pomiędzy mężczyznami a kobietami nie zawsze odbywa się z zachowaniem zasad kultury i wzajemnego szacunku. Choć wydaje się, że dostęp do powszechnego udziału polskich kobiet w przestrzeni politycznej został otwarty, to przytoczone przykłady pokazują, że w rozumieniu wielu parlamentarzystów polityka to wciąż „męska sprawa”: podstawowe ustalenia zapadają pomiędzy mężczyznami, tylko oni wiedzą, co jest ważne. Stereotypowo mężczyźni są racjonalni, kobiety natomiast kierują się głównie emocjami. W ostatnich latach można jednak zauważyć, iż mężczyźni dyskredytują kobiety za pomocą technik, które wcześniej przypisywano głównie kobietom, gdyż to cecha „słabego” (słaby broni się emocjonalnie). Świadczy o tym choćby silna wulgaryzacja języka przytoczonych w niniejszym artykule wypowiedzi polityków-mężczyzn.
\end{abstract}

Słowa kluczowe: dyskurs polityczny, język polityki, strategie komunikacyjno-językowe, stereotyp, deprecjacja oponenta

\section{Założenia}

elem niniejszego artykułu jest przeanalizowanie językowych sposobów jawnej de-
precjacji kobiet przez polskich polityków i publicystów w kontekście działań oraz wypowiedzi wymierzonych przeciwko zaostrzeniu przepisów wynikających z obowiązującej ustawy z dnia 7 stycznia 1993 r. o planowaniu rodziny, ochronie płodu ludzkiego $i$ warunkach dopuszczalności przerywania ciąży ${ }^{1}$. Deprecjacja, będąca emotywno-oceniającym aktem mowy, zaczyna dominować w środowisku konserwatywnej prawicy nie tylko w układach bezpośredniej interakcji, ale staje się charakterystyczna dla publicznej debaty w mediach.

Osoby sprzeciwiające się zmianom w tej ustawie zdecydowały się na organizację w całej Polsce manifestacji ulicznych, nazwanych „czarnymi protestami”2, co było bez-

${ }^{1}$ Dz. U. 2001, Nr 154, poz. 1792.

${ }^{2}$ Nazwanych tak ze względu na czarny kolor ubioru uczestników protestu. 
pośrednią reakcją na obywatelski projekt całkowitego zakazu aborcji, złożony w $2016 \mathrm{r}$. w Sejmie przez działaczy konserwatywnego komitetu „Stop Aborcji”. Zdecydowaną większość manifestantów stanowiły kobiety, które w ten sposób chciały wyrazić swoje przekonania w tej konkretnej kwestii. Skala i zaangażowanie tak licznej grupy oponentów zaskoczyła rządzących i doprowadziła do radykalizacji wypowiedzi po obu stronach sporu politycznego ${ }^{3}$. Z sondażu przeprowadzonego w listopadzie $2016 \mathrm{r}$. przez Centrum Badania Opinii Społecznej w zakresie równouprawnienia płci, reprezentacji kobiet w życiu publicznym, a także ,czarnego protestu" i ewentualnych zmian w prawie aborcyjnym (Polacy o prawach kobiet, 2016) wynika, iż o „czarnych protestach” słyszeli wówczas prawie wszyscy - wiedzę o nich zadeklarowało ponad $90 \%$ badanych. Za pozostawieniem $\mathrm{w}$ niezmienionej formie ustawy dotyczącej warunków przerywania ciąży opowiedziała się natomiast ponad połowa respondentów, zaś $58 \%$ badanych poparła „czarne protesty”. Wśród motywów poparcia na plan pierwszy zdecydowanie wysuwała się obrona praw kobiet rozumianych zarówno jako sprzeciw wobec wszelkich przejawów dyskryminacji ze względu na płeć, jak i też jako prawo do wolności wyboru i kierowania się własnym sumieniem w kwestii aborcji.

Szczególnie silną emocjonalnością języka wypowiedzi charakteryzowały się teksty zamieszczane na forach społecznościowych. Centralnym ich tematem stało się prawo kobiet do decydowania o przerwaniu ciąży w określonych prawem sytuacjach oraz dostępie do wiedzy i środków medycznych odnoszących się do życia seksualnego.

Seksualność człowieka postrzegana jest między innymi przez pryzmat kultury, w której stereotyp odgrywa dominującą rolę. W polskim dyskursie publicznym kobieta jest obrazowana przede wszystkim w oparciu o dwa stereotypy: matki i feministki (Por. Walczewska, 2000). Stały się one przedmiotem metodologicznej konstrukcji niniejszego artykułu.

Metodą badawczą jest analiza dyskursu politycznego uwzględniającego poziom tekstowy (strukturalny) i pragmatyczny. Małgorzata Lisowska-Magdziarz podkreśla, że przy analizie dyskursu pamiętać należy, że celem jest badanie dyskursów w sposób kompleksowy, uwzględniający ścisły związek zachowań językowych, komunikacji i kontekstu społecznego (Lisowska-Magdziarz, 2006, s. 21).

Krytyczna analiza dyskursu (dalej: KAD), z ang. critical discourse analysis, jest jedną z teorii językoznawstwa. Zajmuje się jednak dyskursem w specyficzny sposób - stawiając $\mathrm{w}$ centrum dyskurs rozumiany jako społeczny aspekt komunikacyjnego funkcjonowania językowego ludzi ${ }^{4}$. W niniejszym artykule posłużono się KAD w rozumieniu Habermasa i Foucaulta. Szczególna uwaga została zatem skierowana na konsekwencje komunikowania zastosowanych praktyk językowych, którymi są zmiany społeczne. W podjętej analizie dyskurs rozumiany jest nie tylko w kate-

\footnotetext{
${ }^{3}$ Przykłady wypowiedzi zostaną zaprezentowane w części badawczej niniejszego artykułu.

${ }^{4}$ Angielski lingwista Norman Fairclough, jeden z głównych przedstawicieli kierunku, twierdzi, że KAD dąży do „systematycznego badania ukrytych relacji przyczynowości i determinowania zachodzących pomiędzy (a) tekstami, zdarzeniami i praktykami dyskursywnymi oraz (b) szerszymi strukturami, relacjami i procesami społecznymi i kulturowymi. KAD dąży do odkrycia, jak praktyki, zdarzenia oraz teksty tego typu powstają i jak są ideologicznie kształtowane przez relacje władzy oraz walki o władzę. Celem KAD jest także demaskowanie, w jaki sposób niejawność powiązań pomiędzy dyskursem i społeczeństwem stanowi sama w sobie czynnik zabezpieczający władzę oraz hegemonię" (Duszak, Fairclough, 2008, s. 17).
} 
gorii wymiany komunikacyjnej, ale jako złożona całość, w której język związany jest z ideologią, wiedzą, strategiami społecznymi i komunikacyjnymi. Ścieranie się różnych dyskursów (tu szczególnie medialnego i politycznego) oddziałuje na kształt życia społecznego. Dla KAD ważne jest dostrzeżenie związku pomiędzy badanym tekstem a jego celami oraz kontekstem społecznym, w którym występują (Lisowska-Magdziarz, 2006, s. 23-24).

Analizie zostały poddane wypowiedzi ${ }^{5}$ polityków, dziennikarzy i ekspertów politycznych odnoszące się do wartościowania poglądów i postaw kobiet biorących udział w akcjach protestacyjnych, a występujące $\mathrm{w}$ dyskursie politycznym wyłącznie w wywiadach wyemitowanych $\mathrm{w}$ polskim radiu i telewizji oraz wybranych postach zamieszczonych na portalach społecznościowych, takich jak Facebook i Twitter ${ }^{6}$.

Teza o tym, że w ciągu ostatnich trzech dekad zmiany społeczno-gospodarcze wpłynęły na przeobrażenia w sposobach komunikowania się obu płci w przestrzeni publicznej wydaje się już być potwierdzona w wielu monografiach i artykułach także z zakresu językoznawstwa (Por. Anusiewicz, Handke, 1994; Gajda, 1993, s. 9-14; Głowiński, 1980; Handke, 1994, s. 15-31; Kuczyńska, Dzikowska, 2004; 1980, s. 270; Pakszys, 2000). Przed transformacją systemową w Polsce w dyskursie publicznym obowiązywały konwencje neutralnego, nie ekspresywnego wyrażania opinii zarówno przez kobiety, jak i przez mężczyzn. Jednak to mężczyźni byli tymi mówiącymi o polityce, natomiast kobiety musiały się dostosowywać do konwencji narzuconych przez mężczyzn (Por. Gąsior-Marek, 2015, s. 255-265). Po roku 1989, na podstawie badań przeprowadzonych przez językoznawców i socjologów (Por. Laskowska, 2004; Karwat, 2006; Kołodziejek, 1994, s. 69-74), język debaty publicznej stał się agresywny, bezpośredni, często nawet wulgarny.

Zmiany te z jednej strony odzwierciedlają podziały społeczne oraz konflikty ideologiczne czy ekonomiczne, a z drugiej wskazują na ścieranie się tradycji - mającej korzenie w kulturze lokalnej - z ogólnoświatowymi tendencjami, wynikającymi z unifikacji zachowań kulturowych?

Prowadzi to do tego, że obowiązujące do tej pory konwencje i normy zachowań komunikacyjnych ulegają modyfikacjom w zderzeniu z nowymi zjawiskami społecznymi, kulturowymi czy prawnymi. Dotyczy to także interakcji pomiędzy kobietami i mężczyznami $^{8}$ we wszystkich sferach życia społecznego. Coraz trudniej w debacie publicznej,

${ }^{5}$ Jako wypowiedź polityczna przyjmuję, za Janiną Fras, „formę stosunkowo trwałą pod względem treści politycznej, ponadto kompozycji (budowy) i stylu wypowiedzi, ukształtowaną w zależności od funkcji oraz sytuacji użycia (przede wszystkim oficjalnej)" (Fras, 2005, s. 118).

${ }^{6}$ Przebadano ponad 200 wypowiedzi. Poza wskazanymi portalami społecznościowymi materiały pochodzą zarówno z mediów publicznych (np. TVP1, TVP2, TVP Info, Polskie Radio), jak i stacji komercyjnych (TVN, TVN24, Polsat, Polsat News, TV Republika, Telewizja Trwam, Radio Maryja, Radio ZET, Radio RMF FM, Radio ESKA), a także różnych portali informacyjnych, m.in.: Wirtualna Polska, Interia, Onet, Fronda, Nasz Dziennik, Gazeta Wyborcza, Wprost, Polityka, Rzeczpospolita itp.

${ }^{7}$ W Polsce wpływ na te zmiany mogły mieć na przykład następujące czynniki: szeroki dostęp do informacji (przede wszystkim wskutek Internetu), swobodny przepływ ludzi w Unii Europejskiej, dostęp do zagranicznych rynków pracy i szkolnictwa wyższego, turystyka zagraniczna, procesy globalizacyjne, wymiany kulturowe itp.

${ }^{8}$ Poznawcze podejście do kwestii rodzaju zakłada, że płeć jest podstawową kategorią stosowaną do zrozumienia naszego środowiska społecznego i nawiązywania interakcji (Cross, Markus, 2002, s. 48). 
a przede wszystkim w dyskursie politycznym, o zachowania oparte na obowiązujących dotychczas normach grzeczności językowej ${ }^{9}$. Zanegowaniu uległy reguły konwersacyjne H. P. Grice'a czy też reguły działania komunikacyjnego J. Habermasa (Por. Kiklewicz, 2011, s. 25-38; Habermas, 1999), których istotą było dążenie do kompromisu, a nie akceptacja walki o bezwzględne zwycięstwo.

Z obserwacji autora wynika, że w ostatnich latach także na polskiej scenie politycznej obserwujemy dążenie wszystkich uczestników aktu komunikacji do sukcesu. Prowadzi to do wielu negatywnych zjawisk, które wpływają na poziom debaty. Do walki włączyła się aktywnie część kobiet świadomych faktu, że w demokratycznym społeczeństwie muszą stosować się do przyjętych reguł gry komunikacyjno-językowej.

W kontekście powyższego $\mathrm{w}$ artykule pokazane zostaną wybrane sposoby postrzegania rzeczywistości (Por. Bartmiński, 2006; Anusiewicz, 1999), których granice wyznaczają systemy gramatyczne i leksykalne konkretnego języka oraz społeczne przyzwolenie na wyznaczanie nowych konwencji i norm językowych. Jest to konflikt pomiędzy różnym widzeniem stereotypów utrwalonych w systemie i wynikających $\mathrm{z}$ tego sposobów kategoryzacji świata.

\section{Deprecjacja i agresja}

Elżbieta Sobol definiuje deprecjację jako „pomniejszenie wartości czegoś, przedstawienie czegoś w gorszym świetle" (Sobol, 2002, hasło: deprecjacja, s. 127). W Wielkim słowniku wyrazów bliskoznacznych PWN pod redakcją Mirosława Bańko deprecjacja to „degradacja, spadek, obniżenie” (Wielki stownik, 2005, hasło: deprecjacja, s. 122), a w słowniku synonimów Wojciecha Broniarka deprecjonować to: „dewaluować, degradować, lekceważyć, bagatelizować, dezawuować, poniżać, flekować” (Broniarek, 2005, hasło: deprecjonować, s. 94).

$\mathrm{Z}$ deprecjacja związana jest agresja. W Wielkim stowniku języka polskiego pod redakcją Ewy Dereń i Edwarda Polańskiego agresja definiowana jest jako „napastliwe, brutalne zachowanie się wobec kogoś" (Dereń, Polański, 2008, hasło: agresja, s. 32). Nowy słownik języka polskiego Elżbiety Sobol wskazuje na „zaczepność, napastliwość" (Sobol, 2002, hasło: agresja, s. 5), natomiast w Stowniku języka polskiego pod redakcją Mieczysława Szymczaka agresja to ,zachowanie zmierzające do wyładowania niezadowolenia lub gniewu na osobach lub rzeczach; wroga, napastliwa postawa wobec kogoś" (Slownik, 1994, hasło: agresja, s. 17), definicja została opatrzona kwalifikatorem psych. Z punku widzenia językoznawcy agresję werbalna przedstawiła M. Peisert w pracy Formy i funkcje agresji werbalnej. Próba typologii (Peisert, 2004, s. 41-151), natomiast socjolog Mirosław Karwat wskazał dodatkowo na „popularność manipulatorskich - złośliwych, agresywnych, tendencyjnych metod dyskredytacji”, które jego zdaniem stały się wskaźnikiem patologii życia politycznego w Polsce (Karwat, 2006, s. 15).

${ }_{9}$ Szerzej o tym zjawisku pisze Marcin Poprawa w pracy Telewizyjne debaty polityków jako przykład dyskursu publicznego, w podrozdziale zatytułowanym Najważniejsze zjawiska w języku polityki po roku 1989 (Poprawa, 2009, s. 46-52; Por. także: Marcjanik, 1997). 


\section{Stereotyp a pleć $w$ polityce}

Za Walterem Lippmanem przyjmuję, iż stereotyp jest ,generalizacją tego, co dotyczy grupy ludzi, gdzie identyczna charakterystyka jest przypisana zasadniczo wszystkim jej członkom, niezależnie od rzeczywistych różnic między nimi” (Aronson, Willson, Akert, 1997, s. 543). Raz sformułowane stereotypy są odporne na zmiany, gdyż zawierają uproszczony komponent poznawczy, ułatwiający myślową organizację świata, która pozwala przeciętnym użytkownikom języka zrozumieć otaczającą rzeczywistość (Maćkiewicz, 1999, s. 53).

Stereotypy odzwierciedlają przekonania kulturowe (Nelson, 2003, s. 71), a obraz danej grupy jest obrazem społecznym (powszechnym, rozpowszechnionym, przyjmowanym przez większość) - należy go szukać „w głowie” jednostki, ale jednostki, która jest członkiem rodziny, społeczeństwa, narodu, uczestnikiem pewnej wspólnoty językowej i kulturowej, dziedzicem utrwalanych tradycją pojęć, przekonań, wartości, wizji człowieka i świata (Wojciszke, 2003, s. 23-24).

W mniemaniu licznych polityków odwoływanie się do stereotypów, szczególnie odnoszących się do płci, stanowi ,gwarancję” jasnego i klarownego dla odbiorcy przekazu. To sprawia, że prezentacja rzeczywistości politycznej w oparciu o stereotypizację płciową staje się niezgodna ze stanem faktycznym. Istotny wpływ na ten stan rzeczy mają środki masowego przekazu, które umacniając tego typu stereotypy, oddziałują bezpośrednio na postawy polityków i wyborców (Sznajder, 2007, s. 336). Bezpośrednio decydują o stereotypowej roli kobiet w społeczeństwie, a co za tym idzie, ich aktywności na scenie politycznej.

\section{Płeć w polskiej kulturze}

Historycznie rzecz ujmując, w elitarnej kulturze szlacheckiej, kształtującej modele zachowań kulturowych nie tylko w Polce, ale i w wielu krajach Europy w relacjach między kobietami a mężczyznami dominował ideał damy i rycerza (Pateman, 2014, s. 49), w którym, przyjmując za A. Alichniewicz i M. Michałowską, „dama” była „w opałach” a ,rycerz bez trwogi” (Alichniewicz, Michałowska, 2016, s. 177-185). Sławomira Walczewska w monografii pt. Damy, rycerze i feministki. Kobiecy dyskurs emancypacyjny $w$ Polsce podkreśla, że „... szlachecko-rycerski kontrakt płciowy był czynnikiem decydującym o specyfice kobiecego dyskursu emancypacyjnego w Polsce. Silne konfrontowanie się tego dyskursu $\mathrm{z}$ tak wyrazistym w kulturze polskiej motywem patriarchalnym spowodowało, iż obowiązujące niegdyś zasady grzeczności, rycerskości rozmyły się, a konwencjonalne normy zachowań zostały zaburzone" (Walczewska, 2000, s. 9-10).

Na przestrzeni lat relacje między kobietami a mężczyznami w sferze publicznej znacząco się zmieniły w wyniku ewolucji stosunków polityczno-społecznych i gospodarczych (Helios, Jedlecka, 2016, s. 50-61). Ma to swoje odzwierciedlenie także w dyskursie politycznym. Można w nim dostrzec polaryzację dwóch koncepcji postrzegania społecznych ról typowych dla kobiet - nowoczesnej i konserwatywnej. Takie sposoby percepcji mogą być reprezentowane niezależnie od płci. 
Część kobiet biorących aktywny udział w życiu politycznym przestaje być „damami" w tradycyjnym rozumieniu tego pojęcia. Ich zachowania komunikacyjne charakteryzuje agresja, bezpardonowość wypowiadanych opinii, w czym upodobniają swoje wypowiedzi do wypowiedzi wcześniej typowych wyłącznie dla mężczyzn (ale także kobiet) pochodzących z warstw społecznych o mniejszym kapitale kulturowym (Por. Peisert, 2004, op. cit.; Wielkopolskie, 1959). Także mężczyźni przestają być „rycerzami” nie tylko w odniesieniu do kobiet, ale także w stosunku do przedstawicieli swojej płci. Język agresji staje się więc językiem wielu polityków bez względu na płeć, pochodzenie społeczne czy też wykształcenie (np. posłanki: Krystyna Pawłowicz, Beata Kempa czy Joanna Senyszyn). Przykładowo, w okresie międzywojennym (Por. Kamińska-Szmaj, 1994), łamanie konwencji językowych było nieakceptowane w środowiskach elitarnych i prowadziło do ostracyzmu, a zachowania komunikacyjne tego typu przypisywano jedynie klasom mniej wykształconym.

Obecnie ani reguły funkcjonowania mediów ani reguły uprawiania polityki nie zawierają obligatoryjnie norm przestrzegania grzeczności językowej przez mężczyzn (i kobiety), mimo iż wciąż obowiązują przyjęte wcześniej zasady dobrego wychowania i odpowiednich zachowań językowych (Por. Skudrzyk, 2007, s. 105-121).

Parlament stał się miejscem, w którym przedstawiciele różnych obozów politycznych często wypowiadają się w sposób znieważający oponenta. Metaforycznie rzecz ujmując, mównica stała się areną, na której walczą gladiatorzy, a widzami są nie tylko zebrani na sali sejmowej posłowie i zaproszeni goście, ale także widzowie i słuchacze, którzy za pomocą mediów mogą śledzić tę walkę. Za Jerzym Bralczykiem można przyjąć, że pojawiające się w nowym wymiarze komunikacyjnym polemiki parlamentarne, podziały między rodzącymi się ugrupowaniami politycznymi postrzegane były przez językoznawców jako zachowania wulgaryzujące i brutalizujące przestrzeń społecznej komunikacji. Badacz przyjął tezę, że pojawił się znany z czasów nowomowy typ komunikacji zwany ,językiem zmowy i kłótni” (Bralczyk, 1990, s. 45-47).

Coraz częściej politycy-mężczyźni, w celu dyskredytacji polityków-kobiet lub ogólnie kobiet wyrażających publicznie swoje przekonania polityczne, odwołują się do argumentacji związanej stricte z płcią. Chcąc zdeprecjonować pozycję kobiet w polityce, posługują się inwektywami, obelgami, wulgaryzmami, insynuacjami seksualnymi czy negatywnie nacechowanymi epitetami i metaforami, nawiązującymi np. do słabości kobiet czy ich nadmiernej wrażliwości. Niekiedy stosują też techniki ukrytej agresji językowej. Wpływ na to mają m.in. ekspansja potoczności w języku publicznym i coraz częstsze łamanie konwencji językowych (Por. Kita, 1991, s. 83-90), a także funkcjonowanie środków masowego przekazu, które podsycają rywalizację polityczną.

\section{Matka i feministka}

W każdym społeczeństwie istnieje zestaw norm i konwencji regulujących zachowanie jednostki w obrębie pełnionej przez nią roli. Zawiera on przekazy dotyczące zadań i obowiązków, zachowań i postaw, cech osobowości i cech wyglądu (Malinowska, 2011, s. 7). Matka i feministka to przykłady dwóch stereotypów, które są definiowane skrajnie różnie, a cechy im przypisywane często wykluczają się. Stereotypowo matka jest 
postrzegana w polskim społeczeństwie pozytywnie, stereotyp feministki wzbudza natomiast najczęściej negatywne emocje.

W polskiej kulturze wzór idealnej matki realizuje symbol Matki Polki, który stanowi - jak podkreśla Sławomira Walczewska - „formułę udziału kobiet w polskiej wspólnocie narodowej” (Walczewska, 2005, s. 15). Idealna Matka Polka powinna urodzić syna i pełna poświęcenia wychować go na patriotę (Kudlińska, 2011, s. 60). Jerzy Bartmiński w pracy pt. Polski stereotyp ,,matki” pokazał wyniki trzech ankiet z roku 1990, których przedmiotem był m.in. stereotyp matki. Respondenci spontanicznie definiowali matke nie tylko taksonomicznie - jako „kobietę”, osobę, która „dała życie”, „urodziła”, ale w połowie przypadków także typologicznie, wskazując przede wszystkim na podstawowe funkcje społeczne matki wobec dziecka: „osoba, która rodzi, żywi, wychowuje”, „która rządzi domem”, „,wychowuje dzieci” itp. Młodzi respondenci mieli wyraźną skłonność do mówienia z perspektywy osobistej (np. „osoba, która mnie urodziła i kocha"). W przytoczonych badaniach ankietowych część pytań miała charakter swoiście ukierunkowany, dotyczyła cech matki po pierwsze - „typowej”, po drugie - „prawdziwej” (Bartmiński, 2008, s. 39-41). Do najczęściej wymienianych cech ,typowej” matki należały: miłość (kochająca dzieci, rodzinę), opiekuńczość i nadopiekuńczość, wyrozumiałość, dobroć, troskliwość, czułość, uczuciowość. Pytanie o cechy „prawdziwej” matki przyniosło w odpowiedzi prawie setkę określeń. Najczęstszymi były: miłość (66\% badanych), opiekuńczość, wyrozumiałość, poświęcenie, dobroć, oddanie, czułość. Godne uwagi jest to, że na pierwszych miejscach obu list znalazły się te same cechy: miłość, opiekuńczość i wyrozumiałość.

Andrzej Wejland w pracy pt. Obrazy grup społecznych. Studium metodologiczne stwierdza, iż treść stereotypową wiązaną z nazwą matka odnajdujemy w wyrażeniach takich, jak dobra matka, troskliwa matka oraz w innych, w których występują przymiotniki czuła, pobożna, tkliwa i szczęśliwa (Wejland, 1991s. 63-64). Znamy wyrażenia miłość matczyna czy serce matki. Słowo matkować znaczy „opiekować się kimś, pielęgnować jak matka”" ${ }^{10}$ natomiast być komuś, dla kogo jak matka to tyle co „opiekować się kimś jak własnym dzieckiem, zastępować matkę" (Śliwiński, 1990, s. 71). Określeniu stosunki matki do dziecka służy przysłowie: „Dziecko za rękę, matkę za serce”. Nie można jednak pominąć przy tym wyrażeń zła matka i wyrodna matka ${ }^{11}$.

Zgoła odmiennie prezentuje się stereotypowy obraz polskiej feministki, przedstawianej w publicznym dyskursie zazwyczaj jako kobiety, która nienawidzi mężczyzn. W Nowym słowniku języka polskiego pod redakcją Elżbiety Sobol feministka definiowana jest jako „zwolenniczka i propagatorka feminizmu” (Sobol, 2002, hasło: feministka, s. 201). Wielki stownik wyrazów obcych pod redakcją Arkadiusza Latuska podaje natomiast, że feminizm to ,ruch głoszący hasła społecznego i politycznego rozwoju kobiet” (Wielki stownik, 2008, hasło: feminizm, s. 280).

${ }^{10} \mathrm{~W}$ ankiecie postawiono też pytanie o przedmioty charakterystyczne dla matki. Okazało się, że to przedmioty wysoce konwencjonalne, związane z kuchnią i żywieniem: garnki, naczynia kuchenne, wałek, ścierka, torba na zakupy, pralka, proszek do prania, maszyna do szycia itp. Zespół ten pozostaje w bezpośredniej relacji z typowymi czynnościami matki takimi, jak zakupy, pranie, szycie, i najważniejszą rolą społeczną - żywicielki, opiekunki i wychowawczyni dzieci ((Wejland, 1991, s. 65.)

11 Wyrodna matka to taka, „która postępuje niewłaściwie wobec własnej rodziny, nie spełnia jej oczekiwań, nie ma cech właściwych jej członkom; nikczemna” (Dereń, Polański, 2008, s. 932). 
Lidia Głowacka w artykule pt. Apel sfrustrowanej pani domu, czyli krytycznie o mistyce kobiecości, zauważa, że w latach 60. XX wieku w Ameryce ${ }^{12}$,powszechne było wyśmiewanie się ze sfrustrowanych feministek, które walcząc o prawa, zaburzały swoją prawdziwa naturę. Stawały się brzydkie i pozbawione kobiecości, gdyż zazdrościły możliwości funkcjonowania w społeczeństwie, jaką mają mężczyźni. Stereotypowy pogląd głosi, że kobiety pół wieku walczyły o prawa, a kolejne pół zastanawiały się, co z nimi zrobić" (Głowacka, 2015, s. 460). Te nieokreślone prawa nie były niczym szczególnym dla osób, które urodziły się w świecie, w którym je już posiadano.

W latach 60. ubiegłego stulecia słowo feministka i kobieta pracujaca zawodowo stały się na równi obraźliwe. Mówiono, że feministki były „niezaspokojonymi seksualnie agresywnymi babami, które nienawidziły mężczyzn i nie chciały mieć dzieci" (Głowacka, 2015, s. 461).

Feministki kreowane są na osoby mało atrakcyjne, zakompleksione i sfrustrowane seksualnie, które nie są zdolne do nawiązania długotrwałych związków z mężczyznami, a często również osoby homoseksualne (Friedan, 2012, s. 37). Jednakże Kamila Budrowska w monografii pt. Kobieta i stereotypy. Obraz kobiety w prozie polskiej po roku 1989 zauważa, że niekiedy feministki przedstawia się jako zimne, oschłe, te, które odchodzą pierwsze, zostawiając mężczyznę w stanie depresji (Budrowska, 2000, s. 171).

Elżbieta Pawlak-Hejno (Pawlak-Hejno, 2015, s. 443-445) podjęła próbę odpowiedzi m.in. na pytanie: „Jakie argumenty współtworzące współczesny negatywny obraz medialny feministki znajdują się w polskim zestawie stereotypów i uprzedzeń?”. W tym celu poddała analizie wybrane memy ${ }^{13}$ internetowe $\mathrm{z}$ komentarzem w języku polskim. Badania pokazały, że „najważniejszą" w Polsce feministką jest Kazimiera Szczuka. Na wybór „ikony feminizmu” wpłynęła prawdopodobnie jej osobowość medialna, wyrazisty punkt widzenia i częste występy w roli komentatorki różnych wydarzeń społecznych i politycznych. Pawlak-Hejno podaje, że tym wizualno-werbalnym komunikatom z wykorzystaną podobizną dziennikarki towarzyszyły m.in. następujące hasła: Jak się nazywa najgtupsza kobieta świata? Feministka; Feministka to tak naprawde kobieta niemajaca wtasnego zdania; Nikt mnie nie chciat, to zostatam feministka; Feministka to kobieta, której nie wyszło z mężczyznami; Feministka - stara panna; Żadamy, by traktowano nas tak samo jak tadne kobiety; Feminizm rodzi się w babskiej głowie wyłacznie dlatego, że z chtopem nie wyszto ${ }^{14}$.

\section{Językowe sposoby jawnej deprecjacji kobiet na przykładzie wypowiedzi medialnych}

W mediach i parlamencie można dostrzec zarówno deprecjację kobiet poprzez supozycje i osłabianie wizerunku, jak i bezpośrednią wrogość (jawną agresję językową). Na potrzeby niniejszej pracy przebadano ponad 200 wypowiedzi, jednakże wybrano

${ }^{12}$ W Ameryce była to wówczas już tzw. druga fala feminizmu.

${ }_{13}$ Mem definiuje Pawlak-Hajno jako ,wizualno-werbalny komunikat rozpowszechniany w Internecie w celu komentowania rzeczywistości, wyrażania osobistego stosunku do świata czy propagowania treści humorystycznych" (Pawlak-Hejno, 2015, s. 444).

${ }^{14}$ Wszystkie przykłady są zaczerpnięte z artykułu: E. Pawlak-Hejno, Feministki..., s. 448-449. 
jedynie wyraziste przykłady, tj. najbardziej ekspresywne, nacechowane negatywnym stosunkiem do powodów zorganizowania „czarnych protestów”. Z analizy materiału badawczego wynika, że były to wypowiedzi polityków i sympatyków (dziennikarzy) tych partii ${ }^{15}$, które wyrażały się jednoznacznie przeciw aborcji, a w konsekwencji, także przeciw protestom kobiet.

W dyskursie publicznym feministki często przeciwstawia się ,normalnym kobietom": ciepłym, rodzinnym, spełnionym życiowo i seksualnie, chcąc pokazać tym samym skrajność pomiędzy stereotypem matki i feministki. W takim tonie o uczestniczkach „czarnego protestu” wypowiedział się Witold Waszczykowski (Prawo i Sprawiedliwość) w programie „Jeden na jeden” w Telewizji TVN24:

„To jest kpina! Tego typu protesty mnie oburzają. O to tym paniom chodziło? Czy tak się walczy o dzieci? [...] Trzeba na ten temat rozmawiać poważnie, a nie przebierać się, robić happeningi, krzyczeć głupkowate hasła. To nie jest sposób rozmowy na temat życia i śmierci" (https://www.tvn24.pl/wiadomosci-z-kraju,3/ witold-waszczykowski-w-jeden-na-jeden-o-czarnym-poniedzialku,681035.html).

Wyrażenie „kpina” wskazuje na jednoznacznie negatywny stosunek Waszczykowskiego do uczestniczek ,czarnego protestu”. Po pierwsze, poprzez sformułowanie pytania Czy tak się walczy o dzieci? poseł próbuje nawiązać do stereotypu matki o wydźwięku pozytywnym: ,prawdziwa” i ,typowa” matka to taka, która dba o swoje dzieci, chroni je, troszczy się o nie. Uczestniczki „czarnych protestów”, w jego mniemaniu, to kobiety zepsute i nieodpowiedzialne (złe, wyrodne matki). Wypowiedzi tego typu wpisują się w stały kontekst ideologiczny konserwatystów, którzy uważają, że dominującą sferą życia kobiet jest dom i rodzinna, a nie aktywność zawodowa i społeczna, gdyż taka wymaga nieemocjonalnego, racjonalnego podejścia do wykonywanych zadań. Przekaz ten, według Waszczykowskiego, jest obcy feministce. Po drugie, Waszczykowski postrzega „dobre matki” jako te kobiety, które dają życie, a nie zabijają (To nie jest sposób rozmowy na temat życia i śmierci). Posłużenie się czasownikiem ,przebierać się” ma na celu zbagatelizowanie wagi demonstracji społecznych, sprowadzenie debaty publicznej do poziomu zabawy, farsy, przedstawienia. Natomiast owe ,głupkowate hasła” to bezmyślne roszczenia zwolenniczek aborcji. Formant -owaty ${ }^{16}$ użyty w tym derywacie ma silne zabarwienie ekspresywne, z wyraźną dalszą gradacją negatywną.

Chętnie na tematy społeczne wypowiada się poseł Paweł Kukiz, przewodniczący klubu poselskiego Kukiz'15. Polityk w swoich wypowiedziach wielokrotnie deprecjonował kobiety zarówno na Facebooku, jak i z mównicy sejmowej. W „Kontrwywiadzie” na antenie Radia RMF FM w następujący sposób skrytykował zwolenniczki swobodnego dostępu do aborcji:

„Koniec, kropka. Nie mogę zgodzić się ze względów etycznych na projekt, który mówi: róbta, co chceta ze swoim dzieckiem, bo to moje ciało. Trzeba było zdawać sobie sprawę, komu się dawało to ciało i kiedy się dawało, i jak się dawało, to ciało (Kontrwywiad, 2016).

Taki sposób deprecjacji jest o tyle kontrowersyjny, że sugeruje rozwiązłość i rozpustę kobiet. Mamy tu także przykład asocjacji językowej - róbta, co chceta było częścią tytu-

15 Partie PiS oraz Kukiz' 15.

${ }^{16}$ Glupkowaty - „typowy, charakteryzujący głupka” (Patrz: Gramatyka, 1984, s. 453). 
łu prowadzonego przez Jurka Owsiaka programu (,Róbta co chceta, czyli rock’n'rollowa jazda bez trzymanki”), wyświetlanego w latach 90. Owsiak wielokrotnie podkreślał w mediach, że choć wolność jednostki jest dla niego ważna, to zawsze powinna być podparta odpowiedzialnością. Indywidualizmu nie utożsamiał więc z samowolą i lekkomyślnością. Wydaje się, że podobny wydźwięk ma cytowana wypowiedź Kukiza. Polityk, stosując ostrą retorykę, świadomie obraża zwolenniczki aborcji za brak myślenia o konsekwencjach swoich czynów. Prowokuje, zachęca do dyskusji społecznej. Stosuje także powtórzenie leksemów ciało oraz dawało. Poprzez zastosowanie tego zabiegu stylistycznego podkreśla znaczenie tematu oraz zwiększa ekspresję wypowiedzi. Znacząca jest też forma bezosobowa czasownika.

Feministki atakuje również inny poseł na Sejm VIII kadencji z ugrupowania Kukiz'15 - Marek Jakubiak, który w wywiadzie wyemitowanym na antenie Polskiego Radia 24 powiedział:

„Ruchy feministyczne zaczynają kontestować w ogóle kobiety, czyli szacunek mężczyzny do kobiety. Ja im cały czas mówię, że feminizm kończy się zawsze wtedy, kiedy trzeba lodówkę wnieść na czwarte piętro" (http://nczas.com/ wiadomosci/polska/mocne-slowa-jakubiaka-feminizm-konczy-sie-kiedy-trzebawniesc-lodowke-na-czwarte-pietro-video/).

Polityk podkreśla słabość kobiet - jednakże nie w znaczeniu: subtelność, delikatność, zwiewność, lecz raczej w kontekście negatywnym, tj. jako słabość fizyczną. Chce w ten sposób pokazać zależność kobiet od mężczyzn, sugeruje, że są takie sfery życia, gdzie kobiety, bez pomocy mężczyzn (ich siły), nie poradzą sobie. Sugeruje poniekąd, że feministki są silne i odważne jedynie w słowach, a ich niezależność znika wraz z nadejściem spraw związanych z życiem codziennym.

Negatywnie o zwolenniczkach obowiązującego obecnie tzw. konsensusu aborcyjnego ${ }^{17}$ wypowiadają się także niektórzy dziennikarze polityczni. Rafał Ziemkiewicz, prawicowy publicysta, o uczestniczkach „czarnych protestów” (nie tylko feministkach), które pojawiły się z transparentami pod domem J. Kaczyńskiego na portalu Twitter napisał: „Kobiety? Kobiety nie szwendają się nocą pod cudzym domem wrzeszcząc o swoich cipach i macicach" (https://twitter.com/R_A_Ziemkiewicz). Dziennikarz twierdzi, że „porządne” kobiety siedzą w domu, zajmują się dziećmi. Nie biorą udziału w manifestacjach, nie wyrażają żądań na ulicy, nie angażują się w politykę. Takie zachowania nie przystoją ani damie, ani „dobrej” matce. Czasownik „wrzeszczeć” [bardzo głośno krzyczeć; hałasować; wymyślać komuś (Stownik języka polskiego PWN)] wskazuje na zakłócanie spokoju i agresywną postawę. Podobnie potocyzm „szwendać się” [chodzić bez celu (Ibidem, hasło: szwendać się)] wskazuje na bezmyślne zachowanie uczestni-

${ }^{17} \mathrm{~W}$ polskim prawie aborcja jest dopuszczalna w trzech kwalifikowanych przypadkach:

1) gdy ciąża stanowi zagrożenie dla życia lub zdrowia kobiety ciężarnej (bez ograniczeń ze względu na wiek płodu),

2) gdy badania prenatalne lub inne przesłanki medyczne wskazują na duże prawdopodobieństwo ciężkiego i nieodwracalnego upośledzenia płodu albo nieuleczalnej choroby zagrażającej jego życiu (do chwili osiągnięcia przez płód zdolności do samodzielnego życia poza organizmem kobiety ciężarnej),

3) gdy zachodzi uzasadnione podejrzenie, że ciąża powstała w wyniku czynu zabronionego (do 12 tygodni od początku ciąży) (Patrz: Ustawa z dnia 7 stycznia 1993 r. o planowaniu...). 
czek protestów. R. Ziemkiewicz sugeruje niejako, że dla kobiet przewidziane są delikatniejsze formy protestu, np. listy czy apele. Wulgaryzm „cipa” został natomiast użyty w znaczeniu: ,żeński narząd moczowo-płciowy” (Grochowski, 2008, hasło: cipa, s. 61).

Dziennikarz polityczny Tomasz Terlikowski, redaktor naczelny Telewizji Republika, słynie z kontrowersyjnej działalności w Internecie. Na swoim oficjalnym profilu na $\mathrm{Fa}$ cebooku umieścił zdjęcie munduru funkcjonariuszy SS i oznajmił:
„Dla uczestniczek i uczestników czarnego protestu mam wdzięczne wdzianko na jutro. Ci, co je nosili, też uważali, że silniejsi mogą zabijać słabszych..." (http:// wiadomosci.gazeta.pl/wiadomosci/7,114884,20779905,kiedy-myslisz-ze-gorzej- -byc-nie-moze-skandaliczny-atak-terlikowskiego.html).

Ten przykład należy zaliczyć do tekstu werbalno-wizualnego, bowiem Terlikowski posługuje się także obrazem. Wypowiedź była próbą wyśmiania osób deklarujących swój udział w poniedziałkowym strajku (3 października 2016 r.), któremu towarzyszyć miały czarne stroje. Redaktor naczelny TV Republika tym samym stawia w jednym rzędzie walczących o wolność wyboru Polaków z SS-manami odpowiedzialnymi za zbrodnie III Rzeszy. Przyjmuje a priori, że osoby biorące udział w protestach są zwolennikami aborcji i w związku z tym traktuje je jak morderczynie. Wyrażenie „,wdzięczne wdzianko" ma natomiast wydźwięk ironiczny. Emocjonalnego charakteru tej wypowiedzi nadaje również posłużenie się kontrastem: silniejsi (matki, które zabijaja) - słabsi (nienarodzone dzieci).

Roman Sklepowicz, do niedawna ekspert w Telewizji TVP Info, nie szczędził inwektyw ani wulgaryzmów pod adresem uczestniczek ,czarnego wtorku” (demonstracji, które odbyły się w dużych miastach Polski 3 października 2017 r.):
„-- Ładne laski idą na dyskotekę, a brzydkie, których nikt nie chce bzykać, to idą na demonstrację.
- Patrzyłem na nie i myślałem: Ta? O Jezus, o Boże. Tak stałem i myślałem i do- szedłem do wniosku: kto to rucha? Doszedłem do wniosku, że nikt. I dlatego idą w tej manifestacji” (http://wiadomosci.radiozet.pl/Polska/Sklepowicz-o-Czarnym- Wtorku-Ladne-laski-ida-na-dyskoteke-a-brzydkie-ktorych-nikt-nie-chce-bzykac- na-demonstracje).

Nie sposób nie zauważyć, iż wypowiedzi R. Sklepowicza mają na celu prowokację - elegancka politycznie debata byłaby nieskuteczna, stąd też autor chciał na siebie zwrócić uwagę poprzez wulgarne formułowanie skrajnie prawicowych poglądów. Takie zabiegi marketingowe są charakterystyczne dla celebrytów („nieważne jak mówią, ważne, że mówią"). Dostrzegamy tu potocyzację języka (laski - o kobietach) czy nawet wulgaryzację (bzykać w znaczeniu: „o partnerze aktywnym: gdy ktoś współżyje z kimś seksualnie" (Grochowski, 2008, hasło: bzykać, s. 49)). Użycie wobec kobiet zaimka wskazującego w rodzaju nijakim (to) świadczy o ich uprzedmiotowieniu. Co więcej, Sklepowicz jednoznacznie twierdzi, że w manifestacjach biorą udział jedynie kobiety nieatrakcyjne (brzydkie). Powyższa wypowiedź pozwala rozumieć „seks” jako: zdrowie, spełnienie, szczęście, piękno (coś, co jest właściwe dla ładnych lasek), natomiast jego brak jako: depresję, frustrację, złośliwość, agresję, zgorzkniałość. Taki zabieg można uznać za kontrowersyjny. Z jednej strony, Sklepowicz przekracza granice przyzwoitości i grzeczności językowej, z drugiej zaś - poniża kobiety, odwołując się niejako do 
podstawowych potrzeb biologicznych każdego człowieka (m.in. potrzeby rozładowania napięcia seksualnego). Wulgaryzm „ruchać” został użyty w znaczeniu „mieć stosunek płciowy; współżyć z kimś" (Grochowski, 2008, hasło: ruchać, s. 178). Jest to świadectwo stosunku do norm społecznych, prymitywizmu czy wręcz chamstwa.

Retoryka nienawiści nie jest obca także politykom samorządowym. Grzegorz Szwed, radny dzielnicy Wieniawa w Lublinie (Prawo i Sprawiedliwość), nagrał, a następnie opublikował na Facebook' $u$ wulgarny filmik, w którym obrażał strajkujące kobiety:
„Partia Razem, która chce aborcji, realizuje program Stalina. Dlaczego? A pier- dolcie się, kurwa, jak zwierzęta po lesie. Jak się coś urodzi, to się urodzi, a jak nie to, nie. Upierdolimy, usuniemy, i tak dalej, nie? [...] Jeżeli ktoś dalej będzie promował lewacki marsz, gdzie pierdolą się prostytutki, które chcą się rżnąć, a nie ponosić konsekwencji, to będę takie osoby piętnowal!” (http://pikio.pl/ polityk-o-protestujacych-kobietach-prostytutki-mordujace-ludzi-kuwia-sie-jak- zwierzeta-video/).

Wypowiedź G. Szweda jest wulgarna i skandaliczna. Kobiety, które - w jego ocenie - chcą uprawiać seks bez konsekwencji, a potem mordować Polaków (upierdolimy, usuniemy) nazywa prostytutkami. Obcowanie płciowe określa wulgaryzmami takimi jak rżnać czy pierdolić się. Kobiety porównuje do zwierząt: pierdolcie się jak zwierzęta po lesie. Takie inwektywy o zezwierzęceniu zachowań czy obyczajów deprecjonują godność kobiet. Polityk skrytykował także Partię Razem, która popiera świadome macierzyństwo zarzucając jej, iż realizuje program Stalina, a zatem tzw. „wielką czystkę”, jaka miała miejsce w latach 30. XX wieku w ZSRR. Można odnieść także wrażenie, iż polityk miesza uprawianie seksu, aborcję i antykoncepcję, traktując je niejako na równi. Na podkreślenie zasługuje także fakt, iż radny stosuje otwartą groźbę: będę takie osoby piętnowal.

Popularyzatorem stereotypów o feministkach jest także europoseł Janusz Korwin-Mikke, który na forum Europarlamentu często wypowiada się w sposób kontrowersyjny na temat praw kobiet $\mathrm{i}$ ich miejsca w życiu politycznym ${ }^{18}$. W rozmowie przeprowadzonej w październiku 2016 r. tak wyraził się o przeciwniczkach całkowitego zakazu aborcji:

„Kobieta jest osobą, która kieruje się emocjami. Mężczyźni nie tak bardzo, jak kobiety. Feministki mówią, że kobiety są aborcją żywotnie zainteresowane. Podstawowe prawo rzymskie mówiło, że nie można być sędzią we własnej sprawie. Czyli jak ciąża to sprawa kobiety, to kobiety nie powinny się w tej sprawie wypowiadać, bo nie mogą być dobrymi sędziami. Najważniejszą sprawą są prawa ojca. Jeżeli ojciec ma płacić alimenty, powinien mieć prawo decyzji, czy dziecko zabić, czy nie. W starożytnym Rzymie to mężczyzna miał prawo decydować o zabiciu nawet urodzonego dziecka. Nie znam przypadku by z tego skorzystal,

${ }^{18}$ W marcu 2017 r. Janusz Korwin-Mikke został ukarany przez szefa Parlamentu Europejskiego pozbawieniem diety poselskiej na $30 \mathrm{dni}$, zawieszeniem w działalności poselskiej na 10 dni i utratą prawa reprezentowania PE za wypowiedź, iż kobiety muszą zarabiać mniej, bo „są słabsze, mniejsze i mniej inteligentne". Zdaniem przewodniczącego Parlamentu Europejskiego Antonio Tajaniego, Janusz Korwin-Mikke obrażając kobiety, „okazał pogardę wobec najbardziej fundamentalnych wartości” (http://wyborcza.pl/7,75399,21495625,janusz-korwin-mikke-ukarany-przez-szefa-europarlamentu-zaseksistowska.html?disableRedirects=true). 
ale mial takie prawo. Kobieta nie" (http://wolnosc24.pl/2017/03/04/korwin-mikke-kontra-feministka-z-czarnego-protestu-kobiety-kiedys-rzadzily-teraz-sa-popy chadlem-wideo/).

W pierwszym zdaniu Korwin-Mikke deprecjonuje kobiety uważając, że nie umieją one myśleć ani postępować racjonalnie. Odwołuje się do stereotypu: emocjonalność kobiet versus racjonalność mężczyzn. Dalej twierdzi, że z tego powodu kobiety nie mogą podejmować decyzji. Pisze: Najważniejsza sprawa sa prawa ojca. Aborcja nie jest dla niego eufemizmem, mówi wprost o zabijaniu. W zdaniu Kobiety sa aborcją żywotnie zainteresowane mamy supozycję, że strajkującym chodzi o prawo do aborcji na żądanie, a nie o prawo do aborcji w sytuacji, gdy ciąża stanowi zagrożenie dla życia lub zdrowia kobiety ciężarnej, czy też gdy istnieje duże prawdopodobieństwo ciężkiego i nieodwracalnego upośledzenia płodu. J. Korwin-Mikke pomija zatem fakt, iż wówczas obowiązek opieki nad nieuleczalnie chorym dzieckiem (niezdolnym do samodzielnej egzystencji) spoczywałby przede wszystkim na kobiecie. Polityk utożsamia prawo do decydowania o aborcji jedynie z czynnikiem ekonomicznym, materialnym - łożeniem na wychowanie dziecka (jeżeli ojciec ma płacić alimenty). W celu dyskredytacji kobiet Korwin-Mikke posługuje się asocjacją historyczną poprzez odwołanie się do cywilizacji starożytnych Rzymian. Co więcej, twierdzi, że kobiety nie mogą decydować o swoim ciele, bo - zgodnie z prawem rzymskim - nie moga być sędzia we własnej sprawie. Jest to nawiązanie do łacińskiej paremii prawniczej: Nemo iudex in causa sua (Dębiński, 2009, s. 7), która stanowiła podstawowy warunek bezstronności organu rozstrzygającego sprawę. Odwołując się do prawa rzymskiego, wyraźnie mówi, że ideałem dla niego jest wykluczenie kobiet z życia publicznego, jak miało to miejsce w starożytnym Rzymie. Powyższy argument Korwin-Mikkego wydaje się być chybiony z dwóch powodów: po pierwsze, prawo starorzymskie dotyczyło innego kręgu kulturowego aniżeli chrześcijańska Polska, po drugie, wspomniana zasada miała zastosowanie jedynie w normach prawa stanowionego, podczas gdy tak istotna kwestia światopoglądowa jak prawo do aborcji, w znacznym stopniu dotyczy także norm etycznych, moralnych. Poprzez takie historyczne asocjacje Korwin-Mikke kreuje swój wizerunek erudyty i eksperta.

Ciekawe techniki deprecjacji kobiet pojawiają się w wypowiedzi prezesa Prawa i Sprawiedliwości Jarosława Kaczyńskiego (wywiad z dziennikarzami portalu Onet - Andrzejem Gajcym i Andrzejem Stankiewiczem):

„Kiedy przed siedzibą PiS protestowały kobiety, ale też młode dziewczęta, wykrzykiwały różne rzeczy pod moim adresem, to była to kompletna pomyłka, bo ja z tym projektem nie miałem nic wspólnego. [...] Zresztą protest byl groźny, ale mniej może dla partii, a bardziej dla fundamentów naszego narodowego jestestwa. Bo był w istocie atakiem na Kościół i to atakiem bardzo ostrym" (https://wiadomosci.onet.pl/tylko-w-onecie/jaroslaw-kaczynski-o-aborcji-dzieciz-zespolem-downa-musza-zyc/xplhqb).

Jest to przykład agresji ukrytej. Wypowiedź Jarosława Kaczyńskiego jest ważna o tyle, że jest on przywódcą obecnego obozu prawicy w Polsce. Jako prezes Prawa i Sprawiedliwości występuje nie tylko w imieniu swoim, lecz reprezentuje stanowisko całej partii rządzącej. Kaczyński twierdzi, że protesty były „groźne”, ponieważ stanowiły niebezpieczeństwo dla fundamentów naszego narodowego jestestwa. W ocenie auto- 
ra zagrożenie stanowią także same protestujące kobiety. Użycie wyrażeń „naszego” oraz „narodowego” ma na celu wyrażenie wspólnoty przeżyć i uznawanych wartości, a nawet wprowadza motyw patriotyczny. Co istotne, owym narodowym ,jestestwem"19, według Kaczyńskiego, nie jest na przykład bezpieczeństwo państwa czy konstytucyjnie zagwarantowane wolności i prawa, lecz Kościół. Dostrzegamy tu wyraźny związek ideologii partii prawicowej z nauką Kościoła katolickiego, którą polityk nazywa „fundamentem”. Kaczyński - mówiąc, że „Ordo Iuris zgłosiło projekt, a następnie zniknęło z przestrzeni publicznej jako jego autor i Znaleźliśmy się w trudnej sytuacji [...] Wyszło na to, że jest to nasz projekt” - stosuje strategię „usuwania się z cienia porażki”. Polega ona na zaprzeczeniu związku z osobami, wydarzeniami i okolicznościami naznaczonymi powszechnie negatywną oceną. W tej strategii obronnej stosuje się m.in. zaprzeczanie i tłumaczenie w celu zredukowania odpowiedzialności i związku nadawców z danymi sytuacjami (Leary, 2002, s. 41). Polityk osłabia skalę protestu poprzez negowanie jego legalności, praworządności, akcentując fakt, iż w demonstracji brały udział również osoby niepełnoletnie (,zaangażowanie: wątpliwe z punktu widzenia prawnego - klas szkolnych w ten protest").

W podobnym tonie, co Jarosław Kaczyński na temat „czarnego protestu” wypowiedział się minister obrony narodowej Antoni Macierewicz (Prawo i Sprawiedliwość). Na antenie Telewizji Trwam 7 października 2016 r. oświadczył, iż:

„Wszyscy, którzy przeżyli świadomie ostatnich kilka dni mają pelne rozeznanie, że udało się przeciwnikom Polski doprowadzić do rozniecenia takiej fali absurdalnej i zupelnie niepatrzącej na rzeczywistość nienawiści do Prawa i Sprawiedliwości, do obrońców życia. Gdyby dzisiaj przegłosowano tę ustawę to jedyne, co na pewno mielibyśmy zagwarantowane, to przedłużenie na dni, tygodnie i miesiące narastającego seansu nienawiści do polskości, do Kościoła, do chrześcijaństwa, do narodu. By przeprowadzić ustawę, która ją zagwarantuje. [...] Do tego trzeba jest więcej świadomości społecznej, więcej przekonania, więcej świadomej i skutecznej naszej aktywności. [...] Ale nie ma wątpliwości, ta ustawa z całym pakietem osłonowym, który pokaże jak bardzo nasz rząd wychodzi naprzeciw słusznym i zrozumiałym potrzebom, niepokojom matek i kobiet Polski, wkrótce do Sejmu zostanie skierowana" (https:/www.wprost.pl/kraj/10026119/ Macierewicz-o-posiewie-nienawisci-jakim-zostaly-zatrute-kobiety.html).

Mamy tu wyraźny kontrast dwóch stereotypów: matki i feministki. A. Macierewicz dychotomicznie kategoryzuje: protestujące feministki to kobiety złe, pełne nienawiści, działające nieracjonalnie na szkodę matek, czyli tych „,dobrych” kobiet. To technika deprecjacyjna oparta na polaryzacji, zawierająca odwołania do wartości chrześcijańskich. Polityków Prawa i Sprawiedliwości określa natomiast jako obrońców życia, akcentuje zatem, iż realizują oni pewną misję społeczną. Przeciwnicy partii to wrogowie: polskości, Kościoła, chrześcijaństwa, narodu. Macierewicz sugeruje więc, że w Polsce nie ma miejsca dla innych religii, narodów, wartości. Polityk stara się także załagodzić negatywne nastroje społeczne poprzez zadeklarowanie pomocy dla kobiet, które zdecydują się urodzić dzieci niepełnosprawne (ustawa z pakietem osłonowym, który pokaże, jak

19 Słownik języka polskiego pod red. J. Karłowicza, A. Kryńskiego, W. Niedźwiedzkiego notuje jestestwo z cytatem ze Skargi i Mickiewicza jako: ,istnienie, istność, byt, egzystencja” (Słownik języka polskiego, 1902, hasło: jestestwo, s. 171). 


\section{bardzo nasz rzad wychodzi naprzeciw shusznym i zrozumialym potrzebom, niepokojom matek i kobiet Polski).}

\section{Zakończenie}

$\mathrm{W}$ artykule przedstawiono trzy typowe dla debaty politycznej sposoby deprecjacji kobiet przez mężczyzn, które oparte są na wykluczających się w polskim dyskursie publicznym stereotypach: kobiety-matki i kobiety-feministki:

1) bezpośredni, jawny, brutalny atak werbalny za pomocą wulgaryzmów, inwektyw, gróźb, seksistowskich insynuacji, ironii, a także różnego rodzaju asocjacji i potocyzmów (np. przytoczone wypowiedzi R. Sklepowicza, G. Szweda czy T. Terlikowskiego);

2) agresję ukrytą w stosunku do konkretnej grupy (np. wypowiedź Jarosława Kaczyńskiego);

3) polaryzację: kobiety dobre, czyli matki, a kobiety złe, czyli feministki (np. wypowiedzi A. Macierewicza czy W. Waszczykowskiego). Mamy tu zatem do czynienia $\mathrm{z}$ wartościowaniem.

Z badanych tekstów wynika, iż w dyskursie politycznym coraz trudniej o zachowania oparte na normach obowiązującej dotychczas grzeczności językowej. Batalia pomiędzy mężczyznami a kobietami nie zawsze odbywa się z zachowaniem zasad kultury i wzajemnego szacunku.

Choć wydaje się, że dostęp do czynnego, powszechnego i świadomego udziału polskich kobiet w przestrzeni politycznej został otwarty, to przytoczone przykłady pokazują, że w rozumieniu części parlamentarzystów i publicystów polityka to wciąż „męska sprawa": podstawowe ustalenia zapadają pomiędzy mężczyznami, tylko oni wiedzą, co jest ważne, tylko oni potrafią walczyć o swoje prawa. Chodzi im o walkę merytoryczną (racjonalną), o pojedynek na argumenty, a nie emocje (co mężczyźni przypisują kobietom). Miejsce kobiet wraz ze starcami i dziećmi, jak na feudalnej wojnie, jest w domu. Słynne „Kobiety nie przeszkadzajcie nam, my walczymy o Polskę” z murów strajkującej w 1980 roku stoczni gdańskiej doczekało się licznych komentarzy feministycznych.

Stereotypowo mężczyźni są racjonalni, skrupulatni, merytoryczni, analityczni, kobiety natomiast kierują się głównie emocjami. W ostatnich latach można jednak zauważyć, iż mężczyźni dyskredytują kobiety za pomocą technik, które wcześniej przypisywano głównie kobietom, gdyż to cecha ,słabego" (słaby broni się emocjonalnie). Świadczy o tym choćby silna wulgaryzacja języka przytoczonych w niniejszym artykule wypowiedzi polityków-mężczyzn na tematy związane z polityką aborcyjną.

Ciekawym zjawiskiem w polskiej debacie publicznej jest również wprowadzanie do języka polityki przez polityków-mężczyzn retoryki religijnej. To silne odwoływanie się do wartości chrześcijańskich występuje głównie u polityków o konserwatywnych poglądach, szczególnie przedstawicieli partii Prawo i Sprawiedliwość: Jarosława Kaczyńskiego, Antoniego Macierewicza i Witolda Waszczykowskiego (np. „To nie jest sposób rozmowy na temat życia i śmierci; To narastający seans nienawiści do polskości, do Kościoła, do chrześcijaństwa” czy „Był to w istocie atak na Kościół i to atak bardzo ostry"). 
W badanym w niniejszym artykule okresie (2016-2017) to przede wszystkim wypowiedzi mężczyzn były ekspresywne, silnie nacechowane emocjonalnie, często też wulgarne, to oni oceniali i wartościowali. Podczas drugiej fali strajków kobiet przeciwko zaostrzeniu przepisów dotyczących aborcji, która miała miejsce w 2020 roku, to kobiety używały języka wulgarnego, świadczy o tym choćby hasło przewodnie drugiego etapu protestów: Jebać PiS. Można więc przyjąć, że reakcje kobiet były nie tylko odpowiedzią na działania władzy, ale także na wypowiedzi publiczne mężczyzn.

\section{Bibliografia}

\section{Monografie, prace zbiorowe i artykuły:}

Alichniewicz A., Michałowska M. (2016), „Dama w opałach” i ,rycerz bez trwogi”: stereotypy genderowe w dyskursie biomedycznym i bioetycznym, „Przegląd Filozoficzny”, nr 2, s. 177-185.

Anusiewicz J. (1999), Problematyka językowego obrazu świata w poglądach niektórych językoznawców i filozofów niemieckich XX wieku, w: Językowy obraz świata, red. J. Bartmiński, Lublin, s. 261-289.

Anusiewicz J., Handke K. (1994), Język a kultura. Pteć w języku i kulturze, t. 9, Wrocław.

Aronson E., Willson T. D., Akert R. M. (1997), Psychologia społeczna, thum. A. Bezwińska, W. Domachowski, M. Draheim, E. Hornowska, M. Kowalczyk, Z. Kowalik, M. Zakrzewska, Poznań.

Bartmiński J. (2006), Językowe podstawy obrazu świata, Lublin.

Bartmiński J. (2008), Polski stereotyp „, matki”, „Postscriptum Polonistyczne”, nr 1, s. 33-53.

Bralczyk J. (1990), Antytotalitarny metajęzyk, „Teksty Drugie”, nr 4, s. 45-47.

Broniarek W. (2005), Gdy ci słowa zabraknie. Stownik synonimów, Warszawa.

Budrowska K., Kobieta i stereotypy. Obraz kobiety w prozie polskiej po roku 1989, Białystok 2000.

Cross S. E., Markus H. R. (2002), Płeć w myśleniu, przekonaniach i działaniu: podejście poznawcze, w: Kobiety i mężczyźni: odmienne spojrzenie na różnice, red. B. Wojciszke, Gdańsk, s. 107-127.

Dereń E., Polański E. (2008), Wielki słownik języka polskiego, Kraków.

Dębiński A. (2009), Łacińskie paremie prawnicze a wspótczesna praktyka prawnicza, „Monitor Prawniczy", nr 4.

Duszak A., Fairclough N. (2008), Krytyczna analiza dyskursu. Interdyscyplinarne podejście do komunikacji spotecznej, Kraków.

Fras J. (2005), Komunikacja polityczna. Wybrane zagadnienia gatunków i języka wypowiedzi, Wrocław.

Friedan B. (2012), Mistyka kobiecości, tłum. A. Grzybek, Warszawa.

Gajda S. (1993), Współczesne przemiany w polskiej sytuacji językowej, w: Języki słowiańskie wobec wspótczesnych przemian w Europie, Materiaty konferencji z 23-25.09.1992 r., red. S. Gajda, Opole, s. 9-14.

Gąsior-Marek M. (2015), Kobiety w polityce, w: Feminizm, red. M. Marczewska-Rytko, D. Maj, M. Pomarański, Lublin, s. 255-265.

Głowacka L. (2015), Apel sfrustrowanej pani domu, czyli krytycznie o mistyce kobiecości, w: Feminizm, red. M. Marczewska-Rytko, D. Maj, M. Pomarański, Lublin, s. 457-468.

Głowiński M. (1980), Język a społeczeństwo, Warszawa.

Gramatyka współczesnego języka polskiego. Morfologia (1984), red. R. Grzegorczykowa, R. Laskowski, H. Wróbel, Warszawa. 
Grochowski M. (2008), Stownik polskich przekleństw i wulgaryzmów, Warszawa.

Habermas J. (1999), Teoria działania komunikacyjnego, t. I: Racjonalność działania a racjonalność społeczna, thum. A. Kanikowski, Warszawa.

Handke K. (1994), Język a determinanty ptci, w: Język a kultura. Płeć w języku i kulturze, t. 9, red. J. Anusiewicz, K. Handke, Wrocław, s. 15-31.

Helios J., Jedlecka W. (2016), Wpływ feminizmu na sytuację społeczno-prawna kobiet, Wrocław.

Kamińska-Szmaj I. (1994), Judzi, zohydza, ze czci odziera. Język propagandy politycznej w prasie 1919-1923, Wrocław.

Karwat M. (2006), O złośliwej dyskredytacji. Manipulowanie wizerunkiem przeciwnika, Warszawa.

Kiklewicz A. (2011), Reguly konwersacji H.P. Grice'a: pragmatyka czy semantyka?, „Linguistica Copernicana", nr 2, s. 25-38.

Kita M. (1991), Ekspansja potoczności, „Prace Językoznawcze 19, Studia Polonistyczne”, s. 83-90.

Kołodziejek E. (1994), Językowe środki zwalczania przeciwnika, czyli o inwektywach we współczesnych tekstach politycznych, w: Język a kultura, t. 11: Język polityki a współczesna kultura polityczna, red. J. Anusiewicz, B. Siciński, Wrocław, s. 69-74.

Kuczyńska A., Dzikowska E. K. (2004), Zrozumieć płeć. Studia interdyscyplinarne II, Wrocław.

Kudlińska I. (2011), Społeczne konstruowanie roli (złej) matki - na przykładzie badań nad bezradnościa opiekuńczo-wychowawcza, w: Społeczne konteksty i dylematy realizacji ról płciowych, red. E. Malinowska, „Acta Universitatis Lodziensis. Folia Sociologica”, nr 39, s. 53-72.

Lakoi T. R. (1980), Język a sytuacja kobiety, w: Język w świetle nauki, tłum. T. Holówka, Warszawa, s. 270.

Laskowska E. (2004), Dyskurs parlamentarny w ujęciu komunikacyjnym, Bydgoszcz.

Leary M. (2002), Wywieranie wrażenia na innych. O sztuce autoprezentacji, tłum. A. Kacmajor, M. Kacmajor, Gdańsk.

Lisowska-Magdziarz M. (2006), Analiza tekstu w dyskursie medialnym. Przewodnik dla studentów, Kraków.

Maćkiewicz J. (1999), Kategoryzacja a językowy obraz świata, w: Językowy obraz świata, red. J. Bartmiński, Lublin, s. 47-56.

Malinowska E. (2011), Kapitat ludzki w ujęciu genderowym - koncepcja teoretyczna, w: Społeczne konteksty i dylematy realizacji ról ptciowych, red. E. Malinowska, „Acta Universitatis Lodziensis. Folia Sociologica", nr 39, s. 3-16.

Marcjanik M. (1997), Polska grzeczność językowa, Kielce.

Nelson T. D. (2003), Psychologia uprzedzeń, thum. A. Nowak, Gdańsk.

Pakszys E. (2000), Między natura a kultura: kategoria ptci / rodzaju w poznaniu, Poznań.

Pateman C. (2014), Kontrakt ptci, thum. J. Mikos, Warszawa.

Pawlak-Hejno E. (2015), Feministki, sufrażystki i grumpy cat, w: Feminizm, red. M. Marczewska-Rytko, D. Maj, M. Pomarański, Lublin, s. 443-456.

Peisert M. (2004), Formy i funkcje agresji werbalnej. Próba typologii, Wrocław.

Poprawa M. (2009), Telewizyjne debaty polityków jako przykład dyskursu publicznego, Kraków.

Skudrzyk A. (2007), Normy grzecznościowych zachowań językowych (etykieta językowa, savoir-vivre, bon ton, dobre wychowanie, grzeczność językowa), w: Sztuka czy rzemiosło? Nauczyć Polski i polskiego, red. A. Achtelik, J. Tambor, Katowice, s. 105-121. Słownik języka polskiego (1902), red. J. Karłowicz, A. Kryński, W. Niedźwiedzki, t. 2, Warszawa.

Stownik języka polskiego (1994), red. M. Szymczak, t. I, Warszawa.

Sobol E. (2002), Nowy słownik języka polskiego, Warszawa. 
Sznajder A. (2007), Medialny wizerunek kobiety kandydujacej w Polsce na urzad prezydenta w 2005 roku, Henryki Bochniarz, w: Media w wyborach. Kampanie wyborcze. Media w polityce, red. T. Sasińska-Klas, Toruń, s. 335-351.

Śliwiński W. (1990), Łączliwość składniowo-semantyczna przymiotników z rzeczownikami we wspótczesnym języku polskim, Kraków.

Walczewska S. (2000), Damy, rycerze i feministki. Kobiecy dyskurs emancypacyjny w Polsce, Kraków.

Walczewska S. (2005), Dwie dekady feminizmu, w: Feministki własnym głosem o sobie, red. S. Walczewska, Kraków, s. 5-20.

Wejland A. (1991), Obrazy grup społecznych. Studium metodologiczne, Warszawa.

Wielki stownik wyrazów bliskoznacznych PWN (2005), red. M. Bańko, Warszawa.

Wielki słownik wyrazów obcych (2008), red. A. Latusek, Kraków.

Wielkopolskie Roty Sadowe XIV-XV wieku (1959), t. 1: Roty Poznańskie, oprac. H. Kowalewicz, W. Kuraszkiewicz, Poznań-Wrocław.

Wojciszke B. (2003), Człowiek wśród ludzi. Zarys psychologii społecznej, Warszawa.

\section{Akty prawne:}

Ustawy z dnia 7 stycznia 1993 r. o planowaniu rodziny, ochronie płodu ludzkiego i warunkach dopuszczalności przerywania ciąży, Dz. U. 2001, Nr 154, poz. 1792.

\section{Źródła internetowe:}

http://nczas.com/wiadomosci/polska/mocne-slowa-jakubiaka-feminizm-konczy-sie-kiedy-trzebawniesc-lodowke-na-czwarte-pietro-video/, 10.12.2018.

http://pikio.pl/polityk-o-protestujacych-kobietach-prostytutki-mordujace-ludzi-kuwia-sie-jakzwierzeta-video/, 15.12.2018.

www.rmf24.pl/tylko-w-rmf24/wywiady/kontrwywiad, 10.12.2018.

https://twitter.com/R_A_Ziemkiewicz, 1.12.2018.

https://www.tvn24.pl/wiadomosci-z-kraju,3/witold-waszczykowski-w-jeden-na-jeden-o-czarnymponiedzialku,681035.html, 6.12.2018.

http://wiadomosci.gazeta.pl/wiadomosci/7,114884,20779905,kiedy-myslisz-ze-gorzej-byc-niemoze-skandaliczny-atak-terlikowskiego.html, 6.12.2018.

https://wiadomosci.onet.pl/tylko-w-onecie/jaroslaw-kaczynski-o-aborcji-dzieci-z-zespolem-downamusza-zyc/xplhqb, 25.11.2018.

http://wiadomosci.radiozet.pl/Polska/Sklepowicz-o-Czarnym-Wtorku-Ladne-laski-ida-na-dyskotekea-brzydkie-ktorych-nikt-nie-chce-bzykac-na-demonstracje, 6.12.2018.

http://wolnosc24.pl/2017/03/04/korwin-mikke-kontra-feministka-z-czarnego-protestu-kobiety-kiedysrzadzily-teraz-sa-popychadlem-wideo/, 20.12.2018.

https://www.wprost.pl/kraj/10026119/Macierewicz-o-posiewie-nienawisci-jakim-zostaly-zatrutekobiety.html, 1.12.2018.

http://wyborcza.pl/7,75399,21495625,janusz-korwin-mikke-ukarany-przez-szefa-europarlamentu-za-seksistowska.html?disableRedirects=true, 15.12.2018.

Polacy o prawach kobiet, ,, czarnych protestach” i prawie aborcyjnym, Komunikat z badań CBOS, nr 165/2016, Warszawa, listopad 2016, https://www.cbos.pl/SPISKOM.POL/2016/K_165_16. PDF, 28.02.2021.

Słownik języka polskiego PWN, (online), http://sjp.pwn.pl, 15.12.2018. 


\title{
Methodology of Political Science. The case of Eurasianism
}

\begin{abstract}
Summary
My intention in this article was to show lexical and apparent techniques of women depreciation by Polish politicians and journalists in the context of the statements against tightening the abortion law. People resisting changes in this act decided to organize street demonstrations in Poland, called "black protests". A significant amount of the protestators were women. A human sexuality is perceived in the context of culture where stereotype plays a vital role. In Polish public discourse a woman look is based on two stereotypes: "mother" and "feminist". They were methodological basis of this article construction. It is becoming increasingly difficult to find in a political discourse attitudes based on courtesy. This battle between men and women not always happens in accordance with good manners and respect. Although it looks as access to common women contribution in public life has been opened, mentioned statements show that - in many politician's opinions - politics is still "male business". Stereotypically, men are rational and women are very emotional. But in recent years we may notice that men discredit women by techniques which formerly attributed to women, because it is the main feature of "weak people" (a weak human defends oneself emotionally). This is revealed for instance by the vulgarization of political language (especially male politician's statements which were quoted in this article).
\end{abstract}

Key words: political discourse, the language of politics, linguistic and communicative strategies, stereotype, depreciation of opponent 
